\title{
The EU health claims regulation: impact on the marine lipids
}

Carole KOHLER

RNI Conseil,

2, square La Fayette,

49000 Angers, France

<c.kohler@rni-conseil.com>

\begin{abstract}
European Regulation (EC) No 1924/2006 applies to all types of pre-packed foods for the final consumer, including food intended to supply hospitals, canteens and similar mass caterers, bearing nutrition and health claims. Commercial communications (labelling, presentation or advertising of foods), trade names and other brand names which may be construed as nutrition or health claims are covered by the Regulation. Since the date it was brought into force (15t July 2007), all nutrition and health claims for food products must be authorised prior to the marketing of the products, either by means of a nominative evaluation procedure or a generic evaluation. In light of the provisions of the new Regulation and the transitional measures in effect, what is the future of lipid 'health communication' and more particularly of marine lipid communication? For certain lipids of marine origin (e.g., EPA, DHA, etc.) play an unquestionable nutritional - not to say health - role in the human diet, a fact which is widely accepted by the scientific community.
\end{abstract}

Key words: health claims, nutritional claims, regulation (EC) No 1924/2006, community register, marine lipids, polyunsaturated fatty acids, omega-3 fatty acids

- trade marks and other brand names which may be construed as nutrition or health claims.

It applies to claims relating to all types of foods intended for final consumers, including:

- foods intended for supply to hospitals, canteens, etc.;

- foods supplied without packaging or loose.

\section{Nutrition claims}

Since the $1^{\text {st }}$ July 2007 , all nutrition and health claims for food products must be authorised prior to the marketing of the products, either by means of a nominative evaluation procedure or a generic evaluation.

In light of the provisions of the Regulation, the first and second EFSA opinions batches and rules concerning the transitional periods, what is the future of lipid "health communication" and more particularly of marine lipid communication?

\section{Legislation}

The Regulation (EC) No 1924/2006 applies to all nutrition and health claims including:

- commercial communications (labelling, presentation and promotional campaigns);

\footnotetext{
${ }^{1}$ Regulation (EC) No 1924/2006 of the European Parliament and of the Council of 20 December 2006 on nutrition and health claims made on foods (OJ L 404, 30.12.2006, p. 9).
}

Nutrition claim means any claim which states, suggests or implies that a food has particular beneficial nutritional properties due to:

- the energy (calorific value) it provides; or provides at a reduced or increased rate; or does not provide; and/or

- the nutrients or other substances it contains; or contains in reduced or increased proportions; or does not contain.

In accordance with Article 8 (1) of Regulation (EC) No 1924/2006, nutrition claims are permitted only if they are listed in the Annexe of that Regulation, lastly amended by Regulation (EC) No $116 / 2010^{2}$ and are in conformity with the conditions set out in that Annexe.

\footnotetext{
${ }^{2}$ Regulation (EC) No 116/2010 of 9 February 2010 amending Regulation (EC) No 1924/2006 of the European Parliament and of the Council with regard to the list of nutrition claims (O) L 37, 10.02.2010, p. 16).
}

\section{Health claims}

Health claim means any claim that states, suggests or implies that a relationship exists between a food category, a food or one of its components and health.

As provided for in the Regulation on nutrition and health claims, different types of health claims will be authorised by the Commission. For the first type, the so-called "function" health claims, an EU positive list will be drawn up by the Commission [the so-called Article 13 (1) generic claims list]. This list will consist of well-established health claims relating to the growth, development and the functions of the body [Article 13(1)(a)].

In addition, claims that refer to psychological and behavioural functions [Article 13(1)(b)] and claims on slimming or weight control [Article 13(1)(c)] will be included in this list. For the latter type of claims, it should be noted that claims which make reference to the rate or amount of weight loss remain prohibited under the Regulation.

In accordance with Article 13(5), any additions of health claims [referring to Article 13(1)] to the Community Register based on newly developed scientific data and/or which include a request for the protection of proprietary data are subject to the authorisation procedure. In addition, health claims referring to the reduction of a risk factor in the development of a disease [Article 14(1)(a)] and health claims referring to children's development and health [Article 14(1)(b)] will be authorised, such as "Plant stanol esters have been shown to reduce 
blood cholesterol. Blood cholesterol is a risk factor in the development of coronary heart disease" and "Vitamin D is needed for children's bone growth and development".

\section{Authorisation procedure}

These health claims [Articles 14(1)(a), 14(1)(b) and $13(5)$ ] are subject to the authorisation procedure.

Articles 15 to 18 of Regulation (EC) No 1924/2006 lay down the Community authorisation procedure, which consists of different steps involving the competent national controlling authorities, the European Food Safety Authority (EFSA) and the European Commission.

Applications for authorisation of health claims must be submitted to Member States competent authorities, whose responsibility is to check the admissibility before forwarding it to the EFSA. On 18 April 2008, the Commission adopted implementing rules for applications for authorisation of health claims. The purpose of these implementing rules is to provide a general guide ${ }^{3}$ on the definition and classification of the scientific data needed for the assessment of a health claim. EFSA informs all Member States and the Commission of the application received and gives its opinion within five months. The scientific opinions of EFSA are publicly available on its website ${ }^{4}$.

The applicant and members of the public may make comments to the Commission on EFSA's opinions.

The Commission taking into account the EFSA opinion, the relevant Community Law and other legitimate factors presents a draft decision to the Standing Committee on the Food Chain and Animal Health (SCFCAH) within two months following the notification of the EFSA opinion.

The Commission proposal is then adopted by Comitology (Regulatory Committee) with the scrutiny right of the European Parliament.

All Commission regulations concerning authorisation and refusal of authorisation of health claims [Articles 14(1)(a), 14(1)(b) and 13(5)] made on food are listed in a Community

\footnotetext{
${ }^{3}$ Opinion of the Panel on dietetic products, nutrition and allergies (NDA) on a request from the Commission related to scientific and technical guidance for the preparation and presentation of the application for authorisation of a health claim. Question number: EFSA-Q-2007-066. Adopted: 6 July, 2007. http://www.efsa.europa.eu/en/scdocs/scdoc/530. $\mathrm{htm}$

${ }^{4}$ Official website of the European Food Safety Authority (EFSA): http://www.efsa.europa.eu/en/ nda/ndaclaims.htm
}

Register (the so-called 'Register'). This Community Register has been established as foreseen in Article 20 of Regulation (EC) No 1924/2006; it is updated regularly and is available on the European Commission website ${ }^{5}$.

\section{Next steps of regulation}

\section{Nutrition claims}

The subject of nutrition has not been discussed again between Member States since April 2010. The latest draft of the Commission dated January 2010. The project is still in interdepartmental consultation within the Commission and prompted many discussions among the various services (including interest on the claim "less than X\% of ...", a public health perspective).

Nutrition claims which could be included in the final draft of the second revision would be:

- Reduced to ... / Energy value reduced; Enriched (the threshold should be reduced to $25 \%$ ).

- No added sugar (a clarification should be made in the conditions of use).

- Less than X\% ... not sure of the store.

This revision would be submitted to a vote of SCFCAH at the earliest, the beginning of September 2010.

\section{Article 13(1) generic claims list}

After the first batch of EFSA opinions in October 2009 and a second in February 2010, the next review of EFSA on health claims continue to be made generic batch: the next in September 2010 and the third in 2011.

The Access database ${ }^{6}$ of Article 13(1) health claims contains the 4,637 main health claim entries submitted to EFSA for evaluation and has been updated in May 2010.

In this context, the Commission wants to make decisions on generic claims authorised in batches. The draft decision on the first batch is being discussed between the Member States (about a hundred generic claims) to decide on some labels and conditions of use. "Where the text would be voted at SCFCAH October 2010, it would be published at the earliest beginning in January 2011 which then enter into force in February 2011".

The Commission and Member States have accepted that a limited number of records that

\footnotetext{
${ }^{5}$ Community Register of nutrition and health claims made on food. http://ec.europa.eu/food/ food/labellingnutrition/claims/community_register/ index_en.htm

${ }^{6}$ Consolidated access database of Article 13(1) health claims published in May 2010. http://www. efsa.europa.eu/en/ndaclaims/ndaclaims $13 . \mathrm{htm}$
}

can be completed and reassessed may be eligible for this supplemental application procedure: - Health claims about the micro-organisms had a negative opinion because of a lack of characterisation of microorganism;

- Health claims for which EFSA has concluded that the evidence was not sufficient to establish a causal link.

The list of allegations concerned will be posted on the website of the Commission on or before the date of entry into force of the first list of generic health claims authorised.

There will be a period of three months to resubmit these claims from the entry into force of the first list of permitted claims.

\section{Periods of transition}

A transition period of six months shall apply to enter into force the authorised first commission regulation on generic claims planned normally for February 2011. It means that the transitional periods for using the health claims refused by EFSA should end by August 2011 (figure 1).

Also, the allegations which have never been submitted in Articles 13(1) and 13(5) will be banned after the publication of this first commission regulation.

All generic claims [Article 13(1)] and specific claims [Article 13(5)] still being evaluated in the publication of the first commission regulation can be used during their evaluation and the publication of the appropriate commission decision.

In this respect, it should mean that the EC should confirm that all the specific allegations [Article 13(5)] made before the publication of the first commission regulation will continue to be used during their evaluation and the publication of the appropriate commission decision.

\section{Nutrient profiles}

In addition, in order to bear claims, foods will have to have appropriate nutrient profiles which will be set. This will enhance the consumers' ability to make informed and meaningful choices.

Article 4 of the Regulation foresees the setting of nutrient profiles, via the regulatory committee procedure with European Parliament and Council scrutiny by January 2009.

In simple terms, nutrient profiles will determine whether foods are eligible or not to bear claims, on the basis of their nutrient composition. Nutrient profiles will be based primarily on the levels of nutrients for which excessive intakes in the overall diet are not recommended. 


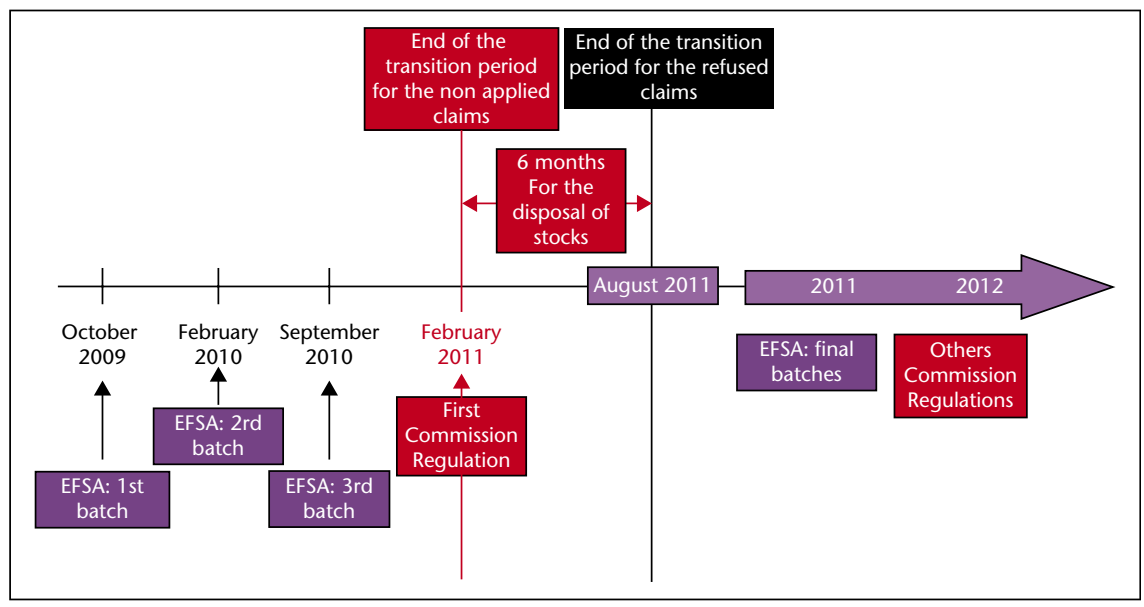

Figure 1. Timetable of the next EFSA and European Commission publication.

The setting of nutrient profiles is a complex exercise that needs to take into account:

- dietary recommendations, public health considerations, and generally acceptable scientific evidence regarding the relationship between diet, nutrition and health, for which the European Food Safety Authority (EFSA) provided a scientific opinion in January 2008; - industrial/commercial considerations, including innovation, cultural and dietary/culinary considerations.

The Commission has conducted specific and extensive consultations of stakeholders on the setting of nutrient profiles. Besides numerous contacts with consumers and public health groups and the different sectors of the food industry, stakeholders were consulted in two meetings of a working group on nutrient profiles of the Advisory Group on the Food Chain and Animal and Plant Health on 8 July and 28 November $2008^{7}$.

Member State experts were consulted within the Commission expert working group on nutrition and health claims, in which EFSA also participated. In the frame of this consultation, many letters have been addressed to DG SANCO, Commissioner Vassiliou, other Commissioners and President Barroso.

In March 2010, members of the European Parliament in the ENVI Committee ${ }^{8}$ had adopted in the context of discussions on the draft regulation of consumer information by

\footnotetext{
${ }^{7}$ Summary report of the Working Groups of the Advisory Group on the Food Chain and Animal and Plant Health on nutrient profiles. Held in Brussels on 8 July and 28 November 2008. http:// ec.europa.eu/food/food/labellingnutrition/claims/ nut_profiles_en.htm

${ }^{8}$ ENVI Committee: The Committee of the European Parliament on the Environment, Public Health and Food Safety.
}

Renate Sommer, an amendment proposing the deletion of nutrient profiles. However, during the first reading vote in Parliament on 16 June 2010, this amendment was ultimately not selected. The Commission should soon make a new proposal for nutrient profiles.

\section{Health claims on the marine lipids}

\section{Nutrition Claims}

\section{Source of vitamin $A$ or vitamin $D$}

A claim that a food is a source of vitamins and/ or minerals, and any claim likely to have the same meaning for the consumer, may only be made where the product contains at least 15\% of the recommended daily allowances (RDAs) specified in the Annexe of the Commission Directive $2008 / 100 / \mathrm{EC}^{9}$ supplied by $100 \mathrm{~g}$ or $100 \mathrm{~mL}$, or per package if the package contains only a single portion (table 1).

\section{High of vitamin A or vitamin D}

A claim that a food is high in vitamins and/or minerals, and any claim likely to have the same meaning for the consumer, may only be made where the product contains at least twice the value of "source of vitamin A or vitamin D".

\section{Source of omega-3 fatty acids}

A claim that a food is a source of omega- 3 fatty acids, and any claim likely to have the same meaning for the consumer, may only be made where the product contains at least $0.3 \mathrm{~g}$ alpha-linolenic acid per $100 \mathrm{~g}$ and per

\footnotetext{
${ }^{9}$ Commission Directive 2008/100/EC of 28 October 2008 amending Council Directive 90/496/EEC on nutrition labelling for foodstuffs as regards recommended daily allowances, energy conversion factors and definitions (OJ L 285, 29.10.2008, p. 9).
}

$100 \mathrm{kcal}$, or at least $40 \mathrm{mg}$ of the sum of eicosapentaenoic acid and docosahexaenoic acid per $100 \mathrm{~g}$ and per $100 \mathrm{kcal}$.

\section{High omega-3 fatty acids}

A claim that a food is high in omega- 3 fatty acids, and any claim likely to have the same meaning for the consumer, may only be made where the product contains at least $0.6 \mathrm{~g}$ alpha-linolenic acid per $100 \mathrm{~g}$ and per $100 \mathrm{kcal}$, or at least $80 \mathrm{mg}$ of the sum of eicosapentaenoic acid and docosahexaenoic acid per $100 \mathrm{~g}$ and per $100 \mathrm{kcal}$.

\section{High monounsaturated fat}

A claim that a food is high in monounsaturated fat, and any claim likely to have the same meaning for the consumer, may only be made where at least $45 \%$ of the fatty acids present in the product derive from monounsaturated fat under the condition that monounsaturated fat provides more than $20 \%$ of energy of the product.

\section{High polyunsaturated fat}

A claim that a food is high in polyunsaturated fat, and any claim likely to have the same meaning for the consumer, may only be made where at least $45 \%$ of the fatty acids present in the product derive from polyunsaturated fat under the condition that polyunsaturated fat provides more than $20 \%$ of energy of the product.

\section{High unsaturated fat}

A claim that a food is high in unsaturated fat, and any claim likely to have the same meaning for the consumer may only be made where at least $70 \%$ of the fatty acids present in the product derive from unsaturated fat under the condition that unsaturated fat provides more than $20 \%$ of energy of the product.

\section{Generic Health Claims Article 13(1)}

Several positive opinions on vitamin $D$ and fatty acids (EPA, DHA and DPA) were given by EFSA and are displayed on the consolidated EFSA access database of Article 13(1) health ${ }^{10}$.

\section{Health Claims Articles 13(5) and 14(1)}

Fifteen opinions concerning health claims Article 13(5) were issued with one positive and none concerning marine lipids [Regulation (EC) No 980/2009, Regulation (EC) No 984/2009, Regulation (EC) No 1025/2009 and Regulation (EC) No 1168/2009].

Sixteen opinions concerning health claims Article 14(1) were issued with fifteen positives concerning lipids whose two positives (table 2) and seventeen negatives (table 3) concerning marine lipids.

\footnotetext{
${ }^{10} \mathrm{http} / / / \mathrm{www}$. efsa.europa.eu/en/ndaclaims/ndaclaims13.htm
} 
Table 1. Nutritional claims authorised concerning lipids - Annexe of the Regulation (EC) 1924/2006.

\begin{tabular}{|lllll|}
\hline Low energy & Energy-reduced & Energy-free & Low fat & Fat-free \\
\hline Low saturated fat & Saturated-fat-free & Low sugars & Sugar-free & With no added sugars \\
\hline Low sodium/salt & Very low sodium/salt & Sodium-free or salt-free & Source of fibre & High fibre \\
\hline Source of protein & High protein & High protein & $\begin{array}{l}\text { Source of [name } \\
\text { of vitamins] and/or } \\
\text { [name of minerals] }\end{array}$ & $\begin{array}{l}\text { High [name } \\
\text { of vitamins] and/or } \\
\text { [name of minerals] }\end{array}$ \\
\hline $\begin{array}{l}\text { Contains [name of the } \\
\text { nutrient or other substance] }\end{array}$ & $\begin{array}{l}\text { Increased [name } \\
\text { of the nutrient] }\end{array}$ & $\begin{array}{l}\text { Reduced [name of the } \\
\text { nutrient] }\end{array}$ & Light/lite & Naturally/natural \\
\hline Source of omega-3 fatty acids & High omega-3 fatty acids & High monounsaturated fat & High polyunsaturated fat & High unsaturated fat \\
\hline
\end{tabular}

Table 2. Health claims [Article 14(1)(b)] authorised concerning marine lipids.

\begin{tabular}{|c|c|c|c|c|}
\hline \multicolumn{5}{|l|}{ Authorised } \\
\hline $\begin{array}{l}\text { Nutrient, substance, } \\
\text { food or food category }\end{array}$ & Claim & $\begin{array}{l}\text { Conditions and/or restrictions of use of the } \\
\text { food and/or additional statement or warning }\end{array}$ & $\begin{array}{l}\text { EFSA opinion } \\
\text { reference }\end{array}$ & $\begin{array}{l}\text { Commission } \\
\text { Regulation }\end{array}$ \\
\hline Calcium and vitamin D & $\begin{array}{l}\text { Calcium and vitamin D } \\
\text { are needed for normal } \\
\text { growth and development } \\
\text { of bone in children. }\end{array}$ & $\begin{array}{l}\text { The claim can be used only for food which is } \\
\text { at least a source of calcium and vitamin D as referred } \\
\text { to in the claim SOURCE OF [NAME OF VITAMIN/S] } \\
\text { AND/OR [NAME OF MINERAL/S] as listed in the } \\
\text { Annexe to Regulation } 1924 / 2006 \text {. }\end{array}$ & Q-2008-116 & $\begin{array}{l}\text { Commission Regulation } \\
\text { (EC) No } 983 / 2009 \\
\text { of } 21 / 10 / 2009\end{array}$ \\
\hline Vitamin D & $\begin{array}{l}\text { Vitamin } D \text { is needed for } \\
\text { normal growth and } \\
\text { development of bone in } \\
\text { children. }\end{array}$ & $\begin{array}{l}\text { The claim can be used only for food which is } \\
\text { at least a source of vitamin D as referred to in the } \\
\text { claim SOURCE OF [NAME OF VITAMIN/S] AND/OR } \\
\text { [NAME OF MINERAL/S] as listed in the Annexe } \\
\text { to Regulation } 1924 / 2006 \text {. }\end{array}$ & Q-2008-323 & $\begin{array}{l}\text { Commission Regulation } \\
\text { (EC) No 983/2009 } \\
\text { of } 21 / 10 / 2009\end{array}$ \\
\hline
\end{tabular}

Table 3. Health claims [Article 14(1)(b)] refused concerning marine lipids.

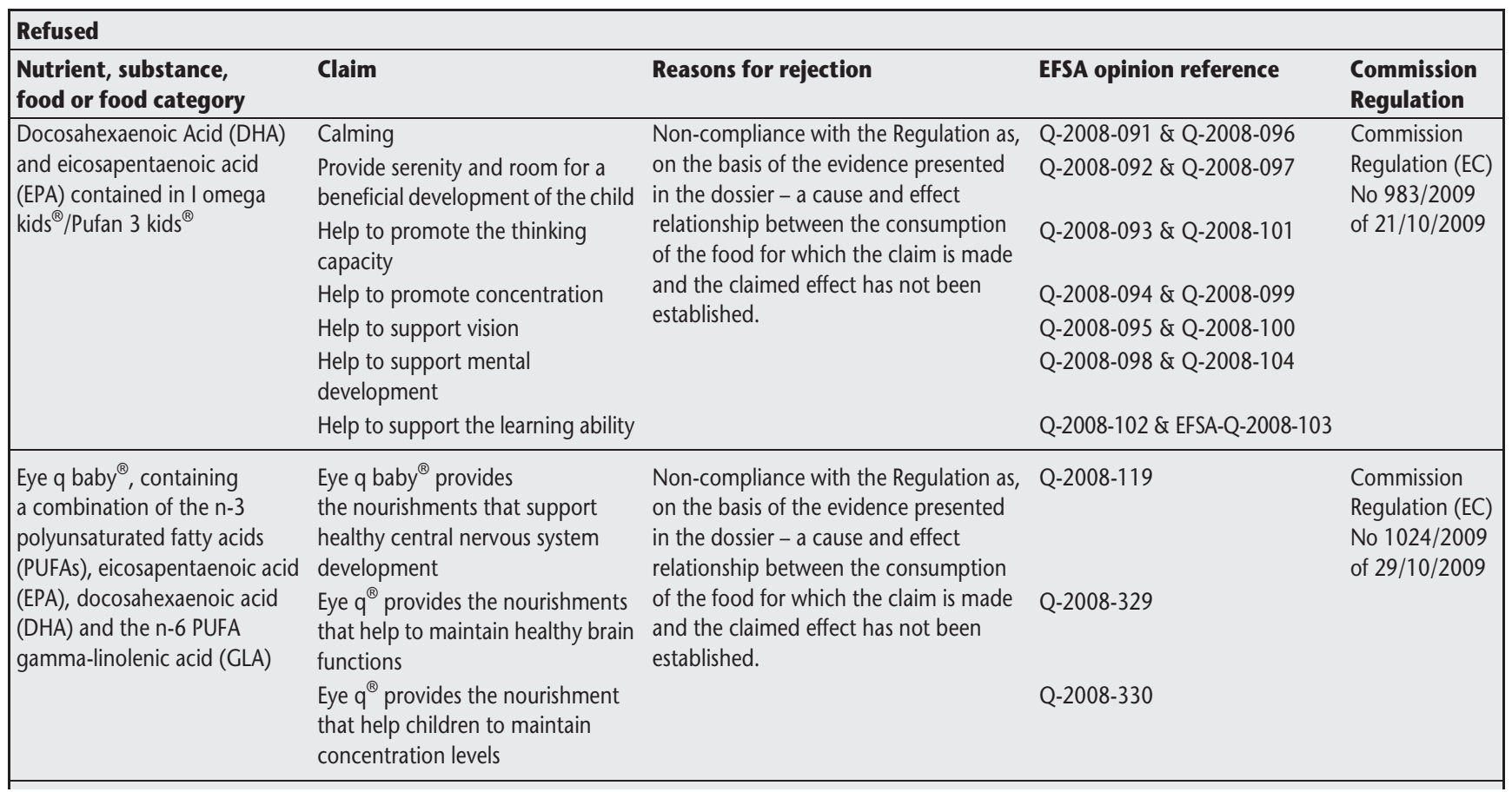




\begin{tabular}{|c|c|c|c|c|}
\hline $\begin{array}{l}\text { Nutrient, substance, } \\
\text { food or food category }\end{array}$ & Claim & Reasons for rejection & EFSA opinion reference & $\begin{array}{l}\text { Commission } \\
\text { Regulation }\end{array}$ \\
\hline $\begin{array}{l}\text { Mumomega }{ }^{\circledR} \text {, containing } \\
\text { a combination of the } n-3 \\
\text { polyunsaturated fatty acids } \\
\text { (PUFAs), eicosapentaenoic acid } \\
\text { (EPA), docosahexaenoic acid } \\
\text { (DHA) and the n-6 PUFA } \\
\text { gamma-linolenic acid (GLA) }\end{array}$ & $\begin{array}{l}\text { Mumomega }{ }^{\circledR} \text { provides } \\
\text { the nourishments that support } \\
\text { healthy central nervous system } \\
\text { development }\end{array}$ & $\begin{array}{l}\text { Non-compliance with the Regulation as, } \\
\text { on the basis of the evidence presented } \\
\text { in the dossier } \\
\text { - a cause and effect relationship between } \\
\text { the consumption of the food for which } \\
\text { the claim is made and the claimed effect } \\
\text { has not been established. }\end{array}$ & Q-2008-328 & $\begin{array}{l}\text { Commission } \\
\text { Regulation (EC) } \\
\text { No } 1024 / 2009 \\
\text { of } 29 / 10 / 2009\end{array}$ \\
\hline $\begin{array}{l}\text { Docosahexaenoic Acid (DHA) } \\
\text { and Arachidonic Acid (ARA) }\end{array}$ & $\begin{array}{l}\text { DHA and ARA support neural } \\
\text { development of the brain and eyes }\end{array}$ & $\begin{array}{l}\text { Non-compliance with the Regulation as, } \\
\text { on the basis of the evidence presented } \\
\text { in the dossier } \\
\text { - a cause and effect relationship between } \\
\text { the consumption of the food for which } \\
\text { the claim is made and the claimed effect } \\
\text { has not been established. }\end{array}$ & Q-2008-120 & $\begin{array}{l}\text { Commission } \\
\text { Regulation (EC) } \\
\text { No } 983 / 2009 \\
\text { of } 21 / 10 / 2009\end{array}$ \\
\hline $\begin{array}{l}\text { Efalex }^{\circledR} \text { products, containing } \\
\text { eicosapentaenoic acid (EPA), } \\
\text { the } n-6 \text { PUFA gamma-linolenic } \\
\text { acid (GLA) and Arachidonic } \\
\text { Acid (ARA) }\end{array}$ & $\begin{array}{l}\text { Efalex }{ }^{\circledR} \text { may help maintain } \\
\text { coordination } \\
\text { Efalex }{ }^{\circledR} \text { may help maintain } \\
\text { concentration } \\
\text { Efalex }{ }^{\circledR} \text { may help maintain } \\
\text { and support brain development } \\
\text { and function } \\
\text { Efalex }{ }^{\circledR} \text { may help maintain learning } \\
\text { ability } \\
\text { Efalex }{ }^{\circledR} \text { may help maintain } \\
\text { and support eye development } \\
\text { and function }\end{array}$ & $\begin{array}{l}\text { Non-compliance with the Regulation as, } \\
\text { on the basis of the evidence presented } \\
\text { in the dossier } \\
\text { - a cause and effect relationship between } \\
\text { the consumption of the food for which } \\
\text { the claim is made and the claimed effect } \\
\text { has not been established. }\end{array}$ & $\begin{array}{l}\text { Q-2008-121 } \\
\text { Q-2008-317 } \\
\text { Q-2008-318 }\end{array}$ & $\begin{array}{l}\text { Commission } \\
\text { Regulation (EC) } \\
\text { No } 1024 / 2009 \\
\text { of } 29 / 10 / 2009\end{array}$ \\
\hline
\end{tabular}

All the regulations mentioned below are published in the Community Register on the European Commission website[6].

\section{Conclusion}

The nutrition and health claims Regulation (EC) No 1924/2006 applies to all commercial communications, trade marks and brand names which may be construed as nutrition or health claims.

Different types of health claims will be authorised by the Commission - generic health claims [Article 13(1)] and specific health claims [Articles 13(5) and 14(1)]: relating to the growth, development and the functions of the body; referring to psychological and behavioural functions, on slimming or weight control; referring to the reduction of a risk factor in the development of a disease; and referring to children's development and health.
Nutrition claims are permitted only if they are listed in the Annexe of the Regulation.

For the generic health claims [Article 13(1)], the first commission regulation is attended for the beginning of next year (February 2011). The publication of these texts will terminate the first transitional period.

For the other health claims, the commission approval or refusal decisions are published in the Community Register.

Three years after the adoption of the nutrition and health claims regulation, what are the results for the lipids, especially marine lipids?

The nutrition claims authorised are referring to the content of vitamin $A$ or $D$, of omega- 3 fatty acids, of monounsaturated fatty acids, of polyunsaturated fatty acids and of unsaturated fatty acids.

One health claim on vitamin D and "normal growth and development of bone in children" is authorised.
All the other claims on polyunsaturated fatty acids, DHA and EPA have been refused because the cause and effect relationship between the consumption of the food and the claimed effect has not been established.

The future for health communications products based on marine lipids is severely restricted. Indeed, as we approach the end of the first transitional period (2011), a vast majority of claims shall be removed from packaging.

In order to properly anticipate the publication of the first commission regulation, it is very important for the industrials to check their packaging, to clearly identify the claims refused and the non-applied claims. And to exit the scope of this regulation, think of other lines of communication like environmental labelling, eco-labels, naturalness, cosmetic claims, allegations of diet products, etc.

It is clear that the next two years will be decisive for the food and nutrition industries. 